\title{
ON THE GARBOHYDRATE COMPOSITION AND NUTRITIVE VALUE OF SOME CEREALS
}

\author{
Maija-Litsa Salo and Kajja Kotilainen \\ Department of Animal Husbandry \\ University of Helsinki
}

Received October 25, 1969

A cereal grain is an one-seeded fruit. The fruit coat (pericarp) envelopes the seed and is fused to the thin seed coat (testa). Together they form a protective coating around the endosperm and the germ (embryo). In barley and oats the kernel is furthermore covered by hulls, which are composed of floral bracts. In barley they are attached to the kernel, but are loose in oats.

The relative proportions of the different grain-parts vary in different species, and therefore differences also occur in the whole meal composition and nutritive value. Table 1 presents information in respect of four cereal grains.

Table 1. The percentages of different grain-parts in some cereals.

\begin{tabular}{|c|c|c|c|c|c|c|}
\hline & Endosperm & $\begin{array}{c}\text { Aleurone } \\
\text { layer }\end{array}$ & Germ & $\begin{array}{l}\text { Fruit and } \\
\text { seed coats }\end{array}$ & Hulls & Ref. \\
\hline Wheat & 90 & $6-7$ & $2-3$ & $4-6$ & - & BRADBURY et al. 1956 \\
\hline$"$ & $83-85$ & $6.5-9.5$ & $1.5-3$ & $4.5-6.5$ & - & MyASNIKOVA et al. 1969 \\
\hline Rye & 78 & 11 & $3-4$ & $7-8$ & - & $"$ \\
\hline Barley & $63-69$ & $12-13$ & & 6 & $10-12$ & $m$ \\
\hline Oat & $50-55$ & $6-8$ & 3 & 3 & $23-32$ & $"$ \\
\hline
\end{tabular}

The outermost layer of the endosperm, the aleurone layer, contains protein, the inner endosperm starch and amorphous protein, gluten. The germ contains lipid and protein, and the coats hemicellulose material (Wolf et al. 1953, Montgomery \& Sмrth 1956, SAlo 1956b). The hulls consist of strawlike material (SALo 1965b).

Wheat bran, a by-product of the flour mills, makes up about 20 per cent of the grain weight. It contains the fruit and seed coats, the germ, the aleurone layer, and a part of the starchy endosperm. In scientific text the term »bran», however, is usually taken to represent the fruit and seed coats alone. 
The cell walls of the endosperm and germ are chiefly composed of hemicellulose material, which can be divided into water-soluble and water-insoluble substances (MoNTGOMERY \& SMith 1956). The water-soluble substances, known as cereal gums, contain araboxylans, glucosans and proteins and yield viscous solutions in water (GILles \& SMrTH 1954, Meredith \& Anderson 1955, Pomeranz 1961). The wheat flour gums amount to $1-1.5 \%$ of the flour (Montgomery \& SMrth 1956). In oat this type of glucosan, called oat lichenin, has been known to make up 2.6-2.9\% of the oat kernel (LETZig 1960). The water-insoluble hemicellulose is likewise mainly composed of xylose, arabinose and glucose (Montgomery \& Smtr 1956, Kulp \& Bechtel 1963, Cole 1967), in addition it contains some galactose (Cole 1967) and traces of mannose (Perlin \& Suzuki 1965).

Investigations of the cereal carbohydrates have usually been concerned with the purely chemical aspects, viz. clarification of the structure and building-units of the endosperm and the germ part. On the other hand, with the exception of starch, little information is available in respect of several important items, for instance, of the total amounts of the different polysaccharides present, and of the composition and digestibility of the husk parts.

In this investigation attempts have been made to elucidate the nutritive aspects of the carbohydrate composition of cereals. The total amounts of the main carbohydrates or carbohydrate groups have been determined, and the distribution of the hemicellulose, cellulose and lignin between the hull and kernel has been investigated. Furthermore, the relative proportions of the different structural units in the hemicellulose have been determined. A method is also proposed for the determination of the cell-wall complex.

\section{Material and methods}

M a t e ri a $1 \mathrm{~s}$. The analysed cereal samples came from the 1968 harvest of the Viik Experimental Farm. In addition to the whole meal analyses, the compositions of the hulls as well as the dehulled grains, are given for oat and barley. Furthermore, the composition is presented for barley flour, which corresponds to white wheat flour, except that the germ is included in the flour. The content of hulls in the oat and barley was 21 and $9 \%$, respectively. Thus the grain quality was better than the average. The wheat bran investigated was of commercial origin. The samples were ground in a Wiley mill, using sieve No 40 .

$\mathrm{M}$ e t h o d s. The carbohydrate compositions and the related amounts of crude lignin, presented in Table 2, have been determined according to the method of SALo (1965a). In the case of starch, however, the determination plan has been improved by an amyloglucosidase method, developed later (SALo \& SALMi 1968).

The cell-wall complex given in Table 3 is the residue after starch digestion, corrected for ash and protein. The sample was extracted with $80 \%$ ethanol, the starch was hydrolysed at $\mathrm{pH} 4.8$ with amyloglucosidase (for 22 hours at $60^{\circ} \mathrm{C}$ ), filtered through a Gooch asbestos crucible, washed with water, dried, and the loss of weight on ignition determined. The protein content was determined separately from another similarly treated sample.

\section{Results and discussion}

Carbohydrate composition of cereals. The results of the carbohydrate, crude protein and ash determinations are given in Table 2. The sugar content 


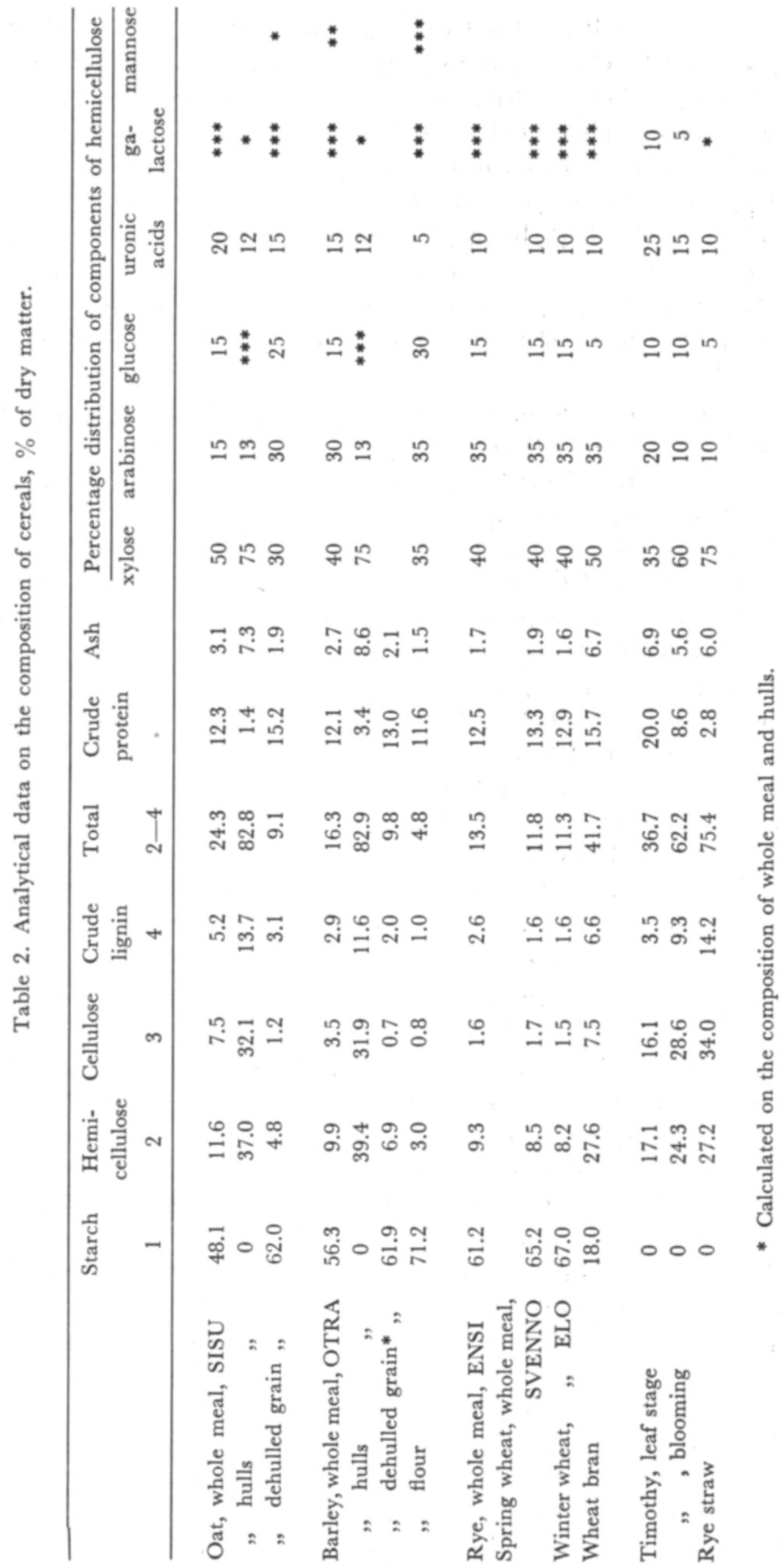


was not determined, since it was known from previous experience that the cereal grains contain only about $1 \%$ of sugar. According to Montgomery and Smrth (1956), cereal sugar is mainly composed of glucofructosan, which is as easily hydrolysable as saccharose. Wheat bran contains 5-6 per cent of sugar (SALO 1965a) indicating that the sugar content of the coats and germ exceeds that of the endosperm. The lipids were not determined; however, to supplement the data, the following contents of crude fat can be given (MYASNKova et al. 1969): oat $4-6 \%$, barley, $2.4 \%$, wheat $1.7-2.3 \%$, and rye $1.7-2.2 \%$.

The data listed in Table 2 indicate that the relative proportions of the hulls and coats, and to some extent also the proportion of the aleurone layer, affect the starch content of the grains. The interpretation of the results is facilitated by concurrent inspection of the data given in Table 1 .

Hemicellulose is the main compound of the oat and barley hulls and the wheat bran. To some extent it also occurs in the endosperm and germ as is observable from the barley flour sample (Table 2). According to published papers (Gilles et al. 1952, Meredith \& Anderson 1955), araboxylan and glucosan have been found in the cell-walls of these grain parts, and the results obtained are thus in conformity with previous findings.

The main component of the kernel hemicellulose are xylose and arabinose, which occur in approximately the same proportions. Also glucose and uronic acid units constitute significant proportions of the hemicellulose. According to paper chromatographic investigation, also traces of galactose were present in all the samples. In addition, traces of mannose were found in barley and oat. The hemicellulose composition of wheat bran closely corresponds to that noted by Wolf et al. (1953) for the pericarp of corn. The uronic acid present in bran is glucuronic acid (Montgomery \& SMrth 1956).

Structurally, the hulled oat and barley grains correspond to the grain of wheat and rye. The composition of the hulled barley grain has been calculated on the composition of hulls $(9 \%)$ and whole meal. The results obtained indicate that the barley sample contained strawlike hulls only to the extent of the 9 per cent mentioned. On the other hand, in comparison with oat, barley contains a larger proportion of the fruit and seed coat part, the bran. This result is in agreement with data in the literature (Myasnikova et al. 1969).

The last three rows of Table 2 present the compositions of leat-stage timothy, blooming timothy and rye straw, respectively, which serve as a comparison-basis for the oat and barley hull data. It can be noted that the compositions of rye straw, oat hulls and barley hulls bear a close resemblance. In fact the hulls are composed of a material which is more wood-like than the straw, because the hulls contain about 10 percentage units more xylose and glucuronic acid polymers than the rye straw. In Table 2 the relative proportions of the hemicellulose components have been rounded off to the nearest five percentage-unit figures; however, it should be mentioned that the uronic acid components in rye straw, oat hulls and barley hulls amounted to 3.6, 4.6 and 5.0 per cent of the dry matter, respectively. The composition of the hulls of oat and barley are very much alike. Lignin and cellulose are typical hull-compounds, whereas in the kernel they occur to a minor extent only.

It can be concluded from the above data that the feed value of the hulls of oat and barley resembles that of the straw. A high content of lignin and xylose units in Gramineaeplants and clover is an indication of their poor digestibility (SALO 1965a). It thus seems 
that the hulls of oat and barley would constitute comparatively poor ruminant forage, and be entirely worthless as fodder for swine and poultry. On the other hand, the feed value of wheat bran is rather high, $0.74-0.76$ feed units $/ \mathrm{kg}$ according to the feed-value Table. Compared with the hulls, the bran contains only a minor proportion of cellulose and lignin (Table 2). The data in Table 2 do not, however, disclose that the pentosans of wheat bran are exceptionally soluble in analytical processes (SALO 1965a), their solubility being even higher than that of the pentosans of young grass. Moreover, they are rather well digested by swine. According to the previous investigation of the author (SALO 1965a), the swine is able to digest nearly 50 per cent of the wheat bran hemicellulose, but only about 15 per cent of its cellulose. Probably the digestibility of the oat and barley bran is of the same category. Investigations into this field cannot be found in the literature.

Determination of the cell-wall complex as the residue a f e r s t a r c h digestion. In Table 3 the sum of the hemicellulose, cellulose and lignin content is compared with the quantity of the cell-wall complex remaining after starch digestion. The complex has been determined by the same method as the first part of the carbohydrate determination scheme. It is noticeable that the protein-corrected residue agrees well with the sum of the fractions. In the determination of starch, extra work is required only for the drying, ashing and weighing, in order to determine the insoluble residue. However, the establishment of the protein correction involves considerably more additional work. Attempts were made to make the protein correction unnecessary by using papain in the amyloglucosidase treatment. The papain decreased the protein content of the residue considerably, though not sufficiently for this purpose. However, the protein correction might possibly be calculated as a percentage-value based upon the total protein content of the grains. From the values presented in Table 3 it can be calculated that the residue contained $72-80$ per cent of the total protein. By analysing a larger series of samples, obviously rather exact correction coefficients would be arrived at, since the treatment involves only extraction with ethanol and enzymatic hydrolysis. It is unlikely that large variations would occur on dissolution of protein from the same grain species.

Table 3. Cell-wall contents of the whole meals ( $\%$ of dry matter), as determined by different methods.

\begin{tabular}{|c|c|c|c|c|c|}
\hline \multirow[t]{2}{*}{ s } & \multirow{2}{*}{$\begin{array}{c}\text { Sum of } \\
\text { columns } \\
2-4 \text { from } \\
\text { Table } 2\end{array}$} & \multicolumn{2}{|c|}{$\begin{array}{c}\text { Residue after starch } \\
\text { digestion }\end{array}$} & \multirow{2}{*}{$\begin{array}{l}\text { Detergent } \\
\text { fibre }\end{array}$} & \multirow{2}{*}{$\begin{array}{l}\text { Crude } \\
\text { fibre }\end{array}$} \\
\hline & & $\begin{array}{l}\text { Cell-wall } \\
\text { complex }\end{array}$ & $\begin{array}{l}\text { Crude } \\
\text { protein }\end{array}$ & & \\
\hline Oat & 24.3 & 24.8 & 9.9 & 25.5 & 10.1 \\
\hline Barley & 16.3 & 16.8 & 9.2 & 14.6 & 4.9 \\
\hline Rye & 13.5 & 13.6 & 9.1 & 11.0 & 2.5 \\
\hline Spring wheat & 11.8 & 11.5 & 9.6 & 8.7 & 2.3 \\
\hline Winter wheat & 11.3 & 10.9 & 9.7 & 8.8 & 2.5 \\
\hline
\end{tabular}

The value of the so-called cell-wall complex determination is reduced by the fact that the term includes the sum of hemicellulose, cellulose and lignin. Of these three, the hemicellulose and cellulose are rather useful in the nutrition of herbivory animals, the lignin, on the other hand, is a worthless substance. Additional information should therefore be obtained regarding the approximate percentages of hemicellulose, cellulose and lignin in 
the complex; at least the proportion of lignin should be reported. The respective percentages for cereals, as calculated from the figures given in Table 2, are given in Table 4.

Percentage-ratios of this kind may well be valid for different samples of the same cereal species. For example, in this investigation no noteworthy differences were detected between the analysed spring and winter wheat samples. However, in respect of grass or clover, for instance, no generally valid ratios can be put forward, as the composition of the cell-wall complex varies depending upon the stage of growth (SALo 1965b).

Table 4. The relative proportions of hemicellulose $(H)$, cellulose $(C)$ and crude lignin $(L)$ in the cell-wall complex.

\begin{tabular}{lccc}
\hline & H & C & L \\
& $\%$ & $\%$ & $\%$ \\
\hline Oat & 48 & 31 & 21 \\
Barley & 61 & 21 & 18 \\
Rye & 69 & 12 & 19 \\
Wheat & $72-73$ & $13-14$ & 14
\end{tabular}

An inaccuracy exists even in specific work in the determination of hemicellulose for oat and barley whole meal; the figure obtained includes the hemicellulose material of both the poorly digestible hulls and the rather well digestible kernel. The composition of the hemicellulose does not sufficiently well explain these facts since the digestibility of the hemicellulose polysaccharides is influenced by the lignin content of the cellular tissue (in the case of swine forage also by the cellulose content) to a larger extent than by the hemicellulose composition proper. From the analytical data presented above it can be calculated that the valuable proportion of the barley whole meal hemicellulose amounts to $64 \%$ or roughly two thirds, whereas in oat this proportion is $33 \%$ or $1 / 3$. In this respect knowledge of the hull-percentage makes a useful pointer.

Results obtained by some fibredetermination methods. The van Soest "neutral detergent fiber» values are also reported in Table 3. The determination was carried out according to the recommended procedure, by boiling for one hour $1 \mathrm{~g}$ of forage with $100 \mathrm{ml}$ of a buffered solution ( $\mathrm{pH} 7.0$ ) of $3 \%$ sodium lauryl sulphate containing $1.86 \%$ of disodium ethylenediamine tetraacetate. The materials were filtered in sintered glass crucibles of coarse porosity, washed with hot water and acetone, dried overnight at $105^{\circ} \mathrm{C}$, and weighed (van Soest 1963a, van Soest \& Marcus 1964).

Since in the above treatment the starch tends to form a suspension, a sintered glass funnel of $\mathrm{Gl}$ porosity was used. The boiled residue could not be filtered through a sinter of finer porosity. For this reason the finest particles were not quantitatively retained in the crucible, which accounted for the poor repeatability of the results. The figures represent the mean of three determinations. It appears that the result is influenced by the hull content of the sample. In oat the mdetergent fiber" is about $5 \%$ higher than the sum of hemicellulose, cellulose and lignin, whereas for barley the figures are about $10 \%$ lower and for rye and wheat $20-25 \%$ lower. Nevertheless, the »detergent fiber» -values include a small amount of both protein and ash. However, van SoEst (1966) himself has remarked that the method has not been successfully applied to concentrates and feedstuffs containing starch because of interference in filtration. 
Several methods have been proposed for the determination of part of the cell-wall substances, for example the "normal-acid fibre» (NAF) of WALKER and his collaborators (e.g. Walker \& Hepburn 1955, Griffith \& Jones 1963), the »lignocellulose» of Jarrige (1960), the macid detergent fiber" of van Soest (1963b) and the "membrane substances" of Palohermo and Palohermo (1949). In the present investigation these methods were not applied, since judging by the author's previous findings (SALO 1965a), at the acid concentration used the first three methods result in a slightly higher figure than the sum of cellulose and lignin presented in Table 2, because in the treatment these two substances and a small part of the hemicellulose remain undissolved. PALohermo's method, on the other hand, yields somewhat higher values as the acid concentration is lower.

The conventional crude fibre percentages are also reported in Table 3 . The figures are lower than those obtainable by the above-mentioned fibre methods, due to the fact that the major part of the lignin dissolves during the treatment. Depending upon the plant material, the crude fibre corresponds to $1-2$ times the cellulose content (SALo 1965b). For the grain samples listed in Table 2, the ratio of crude fibre to cellulose ranges from 1.3 to 1.7 .

Finally it should be noted that the purpose of the present investigation has not been to propose an analytical scheme for routine work, but instead to offer a general idea of the composition of cereal grains, especially their main components, the carbohydrates. General knowledge of the grain composition, along with even limited analyses, aids in the evaluation of the quality of a certain cereal lot. Three simple determinations already yield a rather good practical idea of the feed-value of oat and barley, and only the two latter are required for wheat and rye. These determinations are: 1) percentage of hull, 2) percentage of crude protein, and 3) percentage of starch. If the starch is determined by enzymatic hydrolysis, very little extra work is required for the determination of the cell-wall complex provided that the correction for protein is made on the basis of a percentage-factor. - The conventional crude fibre determination is more or less pointless as a measure of cereal quality.

$S u m$ mary

The contents and the distribution between the different grain parts of starch, hemicellulose, cellulose, crude lignin, crude protein and ash have been determined for oat, barley, rye and two wheat species. The relative proportions of the different structural units of the hemicellulose have also been determined. Furthermore, a method is proposed for the determination of the cell-wall complex in cereals.

Oat and barley differ from wheat and rye to an appreciable extent only in respect of the hull. The hulls consist of strawlike material rich in lignin, cellulose and xylan; they are richer in xylan than the straw proper. The fruit and seed coat enveloping the seed (viz. the bran) contains relatively small amounts of lignin and cellulose. The bran is chiefly composed of hemicellulose with xylose and arabinose as the main components. The main compound of the endosperm is starch, although some hemicellulose and protein are present, whereas only minor amounts of cellulose and lignin can be found. In the samples investigated only small differences were noted between the compositions of wheat, rye, dehulled oat and dehulled barley; wheat had the highest starch content, rye the highest hemicellulose content, and oat the highest contents of crude protein and lignin. 
The cell-wall complex determined as the residue after enzymatic hydrolysis of the starch agreed well with that obtained by fractionation. On the other hand, the detergentfibre values differed from the fractionation results considerably, and the conventional crude fibre analysis yielded results which were about 1.5 times that of cellulose.

The feed-values of the different grain parts are discussed on the basis of the analysis results obtained.

\section{REFERENCES}

Bradbury, D. \& Cull, I. M. \& Macmasters, M. M. 1956. Structure of the mature wheat kernel. I. Gross anatomy and relationships of parts. Cereal Chem. 33: 329-342.

CoLE, E. W. 1967. Isolation and chromatographic fractionation of hemicelluloses from wheat flour. Ibid. 44: $411-416$.

Girles, K. A., Meredith, W. O. S. \& Smith, F. 1952. The carbohydrates of Gramineae. The constitution of the water-soluble polysaccharides of the grain of barley (Hordeum vulgare). Ibid. 29: 314-316.

- - \& S Siтн, F. 1954. The carbohydrates of Gramineae. III. A note on the nature of wheat gum. Ibid. 31: $488-489$.

Griffrth, G. \& Jones, D. I. H. 1963. The normal-acid method for the determination of fibre in roughages. J. Sci. Food. Agric. 14: 380-385.

Jarrige, R. 1960. The membrane constituents of herbage. Proc. 8. Intern. Grassl. Congr. 1960, p. 628 634.

KuLP, K. \& Bechtel, W. G. 1963. Effect of water-insoluble pentosan fraction of wheat endosperm on the quality of white bread. Ibid. 40: 493-504.

LETzig, E. 1960. Über das Haferlichenin und seine quantitative Bestimmung. Nahrung 4: 832-845.

Meredith, W. O. S. \& Anderson, J. A. 1955. Comparisons between malt and barley gums isolated by various procedures. Cereal Chem. 32: 183-191.

Montgomery, R. \& Sмiтн, F. 1956. Cereal components. A review of carbohydrates of wheat and other cereal grains. Agric. Food Chem. 4: 716-720.

Myasnikova, A. V., Rall, Yu. S., Trisvyatskin, L. A. \& Shatilov, S. 1969. Handbook of food products. Grain and its products. 396 p. Jerusalem.

Palohermo, L. \& Palohermo, I. 1949. On the estimation of the total of vegetable membrane substances. J. Sci. Agric. Soc. Finl. 21:1-16.

Perlin, A. S. \& Suzuki, S. 1965. A note on the polysaccharides of wheat flour squeegee. Cereal Chem. 42: 199-201.

Pomeranz, Y. 1961. Cereal gums. Qualitas Plant. Materiae Veget. 8: 158-194.

SALo, M.-L. 1965a. Determination of carbohydrate fractions in animal foods and faeces. Acta Agric. Fenn. 105: 1-102.

- - 1965b. On the content of cell-wall constituents in various plant materials. J. Sci. Agric. Soc. Finl. 37: $127-134$.

—»—\& SALMI, M. 1968. Determination of starch by the amyloglucosidase method. Ibid. 40: 38-45.

van Soest, P. J. 1963a. Use of detergents in the analysis of fibrous feeds. I. Preparation of fiber residues of low nitrogen content. J. A.O.A.C. 46: 825-829.

-» 1963b. II. A rapid method for the determination of fiber and lignin. Ibid. 46: 829 — 835 .

- - 1966. Nonnutritive residues: A system of analysis for the replacement of crude fiber. Ibid. 49: $546-551$. 
- - \& Marcus, W. C. 1964. Method for the determination of cell-wall constituents in forages using detergent and the relationship between this fraction and voluntary intake and digestibility. J. Dairy Sci. 47: 704.

TAo, R. P. \& Pomeranz, Y. 1967. Water-soluble pentosans in flours varying widely in bread-making potential. J. Food Sci. 32: 162-168.

Walker, D. M. \& Hepburn, W. R. 1955. The analysis of roughages by the normal-acid fibre method, and its use for predicting the digestibility of roughages by sheep. Agric. Progr. 30:118-119.

Wolf, M. J., Macmasters, M. M., Cannon, J. A., Rosewall, E. C. \& Rist, C. E. 1953. Preparation and some properties of hemicelluloses from corn hulls. Cereal Chem. 30: 451-470.

\title{
SELOSTUS
}

\section{VILJANJYVIEN HIILIHYDRAATTIKOOSTUMUKSESTA REHUOPILLISELTA KANNALTA TARKASTELTUNA}

\author{
Maija-Litsa Salo ja Kaija Kotilatnen
}

rliopiston kotieläintieteen laitos, Helsinki

Tutkimuksessa on määritetty kaurasta, ohrasta, rukiista ja kevät- sekä syysvehnästä tärkkelys, hemiselluloosa, selluloosa, raakaligniini, raakaproteiini ja tuhka sekä tutkittu näiden aineiden jakautumista jyvän eri osien kesken. Hemiselluloosasta on myös määritetty eri rakenneyksiköiden suhteelliset osuudet. Lisäksi esitetään menetelmä solunseinämäaineksen määrittämiseksi yhteismäärityksenä.

Kaura ja ohra poikkeavat vehnästä ja rukiista oleellisesti vain kuorensa puolesta. Kuoret ovat oljen kaltaista ligniini-, selluloosa- ja ksylaanirikasta ainetta, vielä ksylaanipitoisempaa kuin olki. Hedelmä- ja siemenkuoressa - leseessä - sen sijaan on varsin vähän ligniiniä ja selluloosaa, mutta runsaasti hemiselluloosaa. Ksyloosi, arabinoosi ja glukuronihappo ovat sen pääasialliset rakenneyksiköt. Endosperm sisältää tärkkelyksen ohella melko runsaasti proteiinia ja hemiselluloosaa, mutta vain hyvin vähän selluloosaa ja ligniiniä. Tutkituissa näytteissä erot vehnän, rukiin, kuoritun ohran ja kuoritun kauran välillä olivat vähäiset: tärkkelyspitoisuus oli korkein vehnässä, hemiselluloosapitoisuus korkein rukiissa, raakaproteiinija ligniinipitoisuus korkein kaurassa.

Tärkkelysmäärityksen hydrolyysijäännöksenä määritetty solunseinämäaines täsmäsi hyvin fraktioimalla saadun summan kanssa. Sen sijaan detergenttiä käyttäen määritetty kuitu poikkesi edellä mainituista varsin paljon ja tavanomainen raakakuitu vastasi vain noin 1.5-kertaista selluloosapitoisuutta.

Analyysitulosten perusteella on esitetty kommentteja jyvän eri osien rehuarvosta. 